\title{
The Literary Dimension and Life of Arabic Treatises on Ink Making
}

\author{
Sara Fani
}

\begin{abstract}
In Arabic literary tradition, single ink recipes are scattered in works of different genres, from the alchemical and medical, to those related to calligraphy and penmanship and dedicated to the class of the kuttāb. A handful of treatises stand out for their collection of a significant number of recipes, organized in categories and juxtaposed with other textual sections on different technical crafts. Ranging from the 9 th to the 17 th centuries and from al-Andalus to Yemen, they show a great fluidity in their transmission, fostered by their fragmented structure in short textual units. This contribution presents a series of case studies highlighting the modalities of formation of these compilations and the literary elements that emerge alongside their technical content. This can only be retrieved and properly interpreted by taking into account their literary dimension, which reflects the cultural context in which these treatises have been generated.
\end{abstract}

\section{Keywords}

Arabic literature - compilations of recipes - textual transmission

\section{$1 \quad$ Introduction}

The present enquiry about inks in the Arabo-Islamic manuscript tradition is focused on compilations of technical-artistic recipes on ink making in the Arabic language.* The study considers only those technical works arranged as collections of recipes on ink making that were disseminated and developed as

* The last reviews of this contribution occurred after a change of academic affiliation to the University of Naples "L'Orientale," for the EuQu ERC project (The European Qur'an. Islamic Scripture in European Culture and Religion 1150-1850). 
identifiable textual traditions under the name of an author. ${ }^{1}$ This selection is based upon the original intention of my research, i.e. mapping the procedures and materials employed in ink making in different ages and regions of the Islamic world. For this reason, anonymous works are only considered from a comparative perspective, and not as meaningful sources for a technical history of ink making. ${ }^{2}$ This was the perspective that initially informed my approach to this literary production, and which became the basis for further enquires and chemical experimentations based on the technical content of the texts examined. ${ }^{3}$ Nonetheless, the textual and literary presentation of the technical content are crucial elements for the correct interpretation of the documents. This present contribution will therefore focus on some features of the works in question that demonstrate their literary dimension and aspects of their textual transmission.

Occurrences of single ink recipes within the Arabic literary tradition are attested in various sources. The first ink recipe in Arabic is transmitted in an alchemical treatise, the Kitāb al-hawāsș ('The book of the occult properties') ascribed to Ğābir ibn Ḥayyān (8th c.), one of the main representatives of the

1 The specific aspects that form the focus of this chapter have been developed from my $\mathrm{PhD}$ research on the subject. See Sara Fani, Le arti del libro secondo le fonti arabe originali. I ricettari arabi per la fabbricazione degli inchiostri (sec. ix-xiii): loro importanza per una corretta valutazione e conservazione del patrimonio manoscritto (PhD Diss., University of Naples "L'Orientale," 2013).

2 Anonymous sources are edited in 'Abd al-Lațîf al-Rāwī, 'Abd al-Ilāh Nabhān, "Risāla fì șinācat al-kitāba," Mağallat Mağma' al-lug̉a al-'arabiyya bi-Dimašq = Revue de l'Académie Arabe de Damas, 1987, 62/4: 76o-795; and Idem, "Risāla fị șinā'at al-kitāba (al-qism al-țānī)," Mağallat Mağma' al-luġa al-'arabiyya bi-Dimašq = Revue de l'Académie Arabe de Damas, 1988, 63/1: 50-65; Barwīn Badrī Tawfìq, "Risālatān fī șinā'at al-mahțūṭ al-'arabī," al-Mawrid, 1985, 14/4:275-286; Eugenio Griffini, "Nuovi testi arabo-siculi," in Centenario della nascita di Michele Amari: scritti di filologia e storia araba, di geografia, storia, diritto della Sicilia medievale, studi bizantini e giudaici relativi all'Italia meridionale nel Medio Evo, documenti sulle relazioni fra gli Stati italiani ed il Levante, 2 vols (Palermo: Virzì, 1910), vol. I, pp. 443-448; the latter is translated in Cristina La Rosa, "Alcune ricette per la preparazione degli inchiostri hibr e midād tratte dal Libro del Siciliano: Traduzione del testo e osservazioni," in Islamic Sicily: Philological and Literary Essays, edited by Mirella Cassarino (Quaderni di Studi Arabi n.s., 2015, 10), pp. 173-19o.

3 See the recently discussed PhD thesis by Claudia Colini, From Recipes to Material Analysis: The Arabic Tradition of Black Inks and Paper Coatings (9th to 2oth century) (PhD Diss., University of Hamburg, 2018). 
Arab alchemical tradition. ${ }^{4}$ Ink recipes are also transmitted in treatises on calligraphy being an essential part of the equipment for scribes and copyists; for example, an ink recipe is recorded by the famous calligrapher Ibn Muqla (9th-1oth c.) in his work Risāla fíal-hatt wa-l-qalam ('Short treatise on calligraphy and reed pen'). ${ }^{5}$ Moreover, in a commentary on the poetical work ascribed to another famous calligrapher, Ibn al-Bawwāb (10th-11th c.), entitled Räiyya fi al-haț ('The poem in rhyme $R \bar{a}$ ' on calligraphy'), two recipes by Ibn al-Bawwāb and others by his commentators are reported. ${ }^{6}$ Ink recipes are also attested in manuals compiled by and for the class of the kuttāb (sing. kātib, court chancellors, clerks or secretaries) such as al-Risāla al-'adrä' ('The virgin epistle'), a short treatise on epistolary prose by al-Šaybāni (second half of the 9 th c.), ${ }^{7}$ or

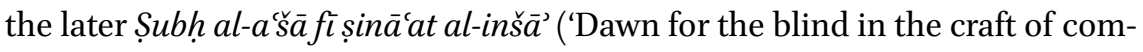
position') by Abū al-'Abbās al-Qalqašandī (756-821/1355-1418). ${ }^{8}$

Another genre in which ink recipes appear deserves to be mentioned for the peculiar social and cultural context in which it was produced; it was in fact,

4 Manfred Ullmann, Die Natur- und Geheimwissenschaften in Islam (Leiden: Brill, 1972), p. 408; Armin Schopen, Tinten und Tuschen des Arabisch-islamischen Mittelalters: Dokumentation, Analyse, Rekonstruktion; ein Beitrag zur materiellen Kultur des Vorderen Orients (Göttingen: Vandenhoeck \& Ruprecht, 20o6), pp. ${ }^{36-37}$, n. 2. For an excursus of the specific genre of books of properties (manāfi' and hawāsș ), see Lucia Raggetti, “The 'Science of Properties' and its Transmission," in In the Wake of the Compendia. Infrastructural Contexts and the Licensing of Empiricism in Ancient and Medieval Mesopotamia, edited by J. Cale Johnson (Berlin/ Boston: De Gruyter, 2015), pp. 159-176 and Eadem, 'İsā ibn 'Al’’s Book on the Useful Properties of Animal Parts. Edition, Translation and Study of a Fluid Tradition (Berlin/Boston: De Gruyter, 2018), pp. xiv-xvi.

5 Dominique Sourdel, "Ibn Mukla," in Encyclopaedia of Islam, New Edition, ed. by Peri J. Bearman, Thierry Bianquis, Clifford E. Bosworth, Emeri J. van Donzel, Wolfhart P. Heinrichs vol. III pp. 886b-887a; Abū 'Alī Muḥammad b. 'Alī Ibn Muqla, "Nașș risālat Ibn Muqla fì al-ḩațt wa-l-qalam," in Ibn Muqla, hatț̣ạtan wa-adīban wa-insānan, edited by Hilāl Nāḡì (Bağdād: Dār al-šu'ūn al-țaqāfiyya al-'āmma, 1991), pp. 115-116.

6 Janine Sourdel-Thomine, "Ibn al-Bawwāb," in Encyclopaedia of Islam, New Edition (cit. note 5), vol. III pp. 736b-737a; David James, "The Commentaries of Ibn al-Bașịs and Ibn al-Wahīd on Ibn al-Bawwāb's Ode on the Art of Calligraphy (Rä̀iyyah fì al-hatțt)," in Back to the Sources. Biblical and Near Eastern Studies in Honour of Dermot Ryan, edited by K.J. Cathcart and J.F. Healey (Dublin: Glendale, 1989), pp. 172-173, 188-189.

7 Ibrāhīm Ibn al-Mudabbir, Risālat al-'ad̆rä = Etude critique sur La lettre vierge d'Ibn el-Mudabber, ed. by Zākī Mubārak (al-Qāhira: Dār al-kutub al-mișriyya / Paris: Maisonneuve Frères, 1350/1931). In this edition, the work was ascribed to Ibrāhīm Ibn al-Mudabbir (m. 279/893) who was its dedicatee (cf. Dominique Sourdel, "Le 'Livre des secrétaires' de 'Abd Allāh al-Baghdādī," Bulletin d'Etudes Orientales, 1952-1954, 14:115-153, p. 116, note 2).

8 Abū al-'Abbās Aḥmad b. 'Alī al-Qalqašāndī, Șuḅ al-a šã fí șinā'at al-inšă', 14 vols (al-Qāhira: Mațba'a al-amīriyya, 1918), Vol. 2, p. 465. 
within the milieu of the Banū Sāsān that Muḥammad ibn Abī Bakr al-Zarhūūī (9th/15th c.) compiled his Kitāb zahr al-basātinn ('Book of the flowers of the gardens'). The recipes transmitted by this source were part of the corpus emanating from an urban Islamic "underworld" comprised of magicians, fortune tellers, herbalists, illusionists, etc. that had the specific aim of amazing the public with astonishing effects. ${ }^{9}$

A few procedures related to the production of black and coloured inks are also attested in treatises related to medicinal, or better, natural remedies; for example, Al-urğūza al-fașịha fì al-a'māl al-șaḥihha ('The eloquent poem in Rağaz verses on the right crafts') by Abū Bakr Ibn Yahyā al-Kātib al-Ȟarrāț, ${ }^{10}$ which features a number of ink recipes grouped by procedures for different daily personal and domestic concerns, such as removing stains from clothes, pest control (insects and other animals), medical preparations and dietary indications. This is not the only example in which the recipes are written in verse, as attested by its title (urğuza), ${ }^{11}$ and it is interesting to note that, in this case, it is the author himself who explains the advantages of a rhymed composition: because it is "easy to remember by heart and to transmit" (sahl fi hifzihi wa-naqlihī). ${ }^{12}$

A similar work is attested in a manuscript collected, and possibly commissioned, by the famous traveller James Bruce (1730-1794). The manuscript, now kept in the Bodleian Library in Oxford (Ms Bruce 45, ff. 10v-25v), ${ }^{13}$ is a codicological curiosity as it was copied onto parchment in the 18th century, in Ethiopia (Gondar), where Arabo-Islamic manuscripts were usually transmitted on paper. The work is entitled Kitāb al-Azraq fi al-țibb ('Al-Azraq's

$9 \quad$ Lucia Raggetti, "Cum Grano Salis. Some Arabic Ink Recipes in Their Historical and Literary Context," Journal of Islamic Manuscripts, 2017, 7:294-338, pp. 328-334 and Clifford E. Bosworth, The Mediaeval Islamic Underworld: The Banū Sāsān in Arabic Society and Literature, 2 vols (Leiden: Brill, 1976).

10 Carl Brockelmann, Geschichte der Arabischen Litteratur. Zweiter Supplementband (Leiden: Brill, 1938), p. 1029. The work is attested in a manuscript in Gotha (ms. orient. A 1327) and in two manuscripts in Paris: BnF Ar. 2776, ff. 64r-71r and BnF 6844, ff. 134v-141r, copied at the end of Dū al-Hiğğa 986 H/February 1579 CE.

11 One case is represented by the above-mentioned poem by Ibn al-Bawwāb, for others cf. Colini, From recipes (cit. note 3), pp. 57-58.

12 See Ms Paris, BnF Ar. 2776, f. 64v, ll. 7-8. For similar mnemotechnical features in Western treatises on colour making, see Sandro Baroni, Paola Travaglio, "Mnemotecnica e aspetti di oralità nei ricettari di tecniche dell'arte e dell'artigianato," Studi di Memofonte, 2016, 16:114-129.

13 Emilie Savage-Smith, A New Catalogue of Arabic Manuscripts in the Bodleian Library, University of Oxford. Volume I: Medicine (Oxford: Oxford University Press, 2011), pp. 429430, entry n. 107. See also the database of the ERC project Islam in the Horn of Africa, where the manuscript has been described by the present author (<http://islhornafr.tors. sc.ku.dk/backend/texts/5143>, last accessed February 2019). 
book on medicine'), attributed to Aḥmad al-'Abdallāwī al-Maḥallawì (fl. 1770), and seems to be an excerpt of a Yemeni medical treatise by Ibrāhīm b. 'Abd al-Raḥmān b. Abī Bakr (b.) al-Azraq (fl. 89o/1485), which is kept in the same collection, but copied - on paper - some decades before Bruce's stay in the region. ${ }^{14}$ The few recipes transmitted in these manuscripts are dedicated to coloured inks (līqa).

\section{3}

\section{Compilations of Ink Making Recipes}

A small number of treatises developed sections dedicated to ink making, describing a considerable number of recipes and organizing them in groups according to their characteristics; these chapters are juxtaposed with sections related to other kinds of recipes or instructions for different technical craftmanships. The present analysis primarily focuses on compilations produced until the 13th century, a time span that represents the period commonly identified as the Golden Age of classical Arabo-Islamic civilization and its literary productions. Nonetheless, later compilations on inks show a degree of originality and deserve specific attention, also with reference and in comparison to the more ancient traditions. ${ }^{15} \mathrm{~A}$ brief description of the sources will be given in order to attest their available editions or witnesses and their general content. ${ }^{16}$

The Zinatal-kataba ('The ornament of the scribes'), is the oldest known technical treatise dealing with sets of ink. It is ascribed to Abū Bakr Muhammad b. Zakariyyā' al-Rāzì (d. 313/925), one of the most famous medieval physicians and alchemists, born in Rayy where he was educated according to the Greek scientific tradition. The above-mentioned short essay is known only through one witness (dated 907/1502), found in the Dār al-Kutub, Cairo, in 2010 and now published. ${ }^{17}$ The short treatise focuses solely on the preparation of black

\footnotetext{
14 MS Oxford, Bodleian Library, Bruce 7 described in Savage-Smith, A New Catalogue (cit. note 13), pp. $73^{8-741}$, entry n. 218.

15 Among the later sources are the treatises by al-Dimašqī (1oth/16th c.) and al-Magiribī (11th/17th c.); for the former, see Raggetti, "Cum grano salis" (cit. note 9), pp. 334-337. For the relevant chapter in Ibn al-Ǧazarī (751-833/1350-1429), see Lucia Raggetti, "Inks as Instruments of Writing. Ibn al-Ǧazarı̄'s Book on the Art of Penmanship," Journal of Islamic Manuscripts, 2019, 10:201-239.

16 A complete translation for the parts of the treatises related to ink making is in Fani, Le arti del libro (cit. note 1), pp. 39-154.

17 Muḥammad ibn Zakariyyā’ al-Rāzī, "Zīnat al-kataba," edited by Luṭf Allāh al-Q̄ārī, 'Ālam al-Mahtūtụāt wa-l-Nawādir, 1432/2011, 16/2:211-242. See also Mahmoud Zaki, "Early Arabic Bookmaking Techniques as Described by al-Rāzī in His Recently Rediscovered Zìnat al-Katabah," Journal of Islamic Manuscripts, 2011, 2:223-234.
} 
inks and invisible inks. ${ }^{18}$ The work also includes recipes for treatments related to writing supports, such as the sizing of the paper and the reuse (as tirs, 'palimpsest') or antiquing of parchment, as well as for the removal of traces of ink or other substances from writing surfaces and fabrics. Indeed, the largest part of the work is dedicated to this latter subject. Other sporadic indications include hair dyeing and the sharpening of knives and swords. Looking at the unique witness of the work, the text is not visibly divided into chapters, but every recipe is introduced by an identifying heading.

The work 'Umdat al-kuttāb wa-'uddat dawī al-albāb ('The staff of the scribes and the implement of the wise men'), has long been considered the most ancient treatise dedicated to the art of the book and, as such, has aroused much interest in both the Arab world and the West; this particular attention is underpinned by the existence of numerous witnesses to the text still preserved in libraries, dating back to different periods and coming from different geographical areas. ${ }^{19}$ The treatise is traditionally ascribed to al-Mu'izz Ibn Bādīs (399-454/10o8-1061), the Zirid governor of Ifrīqiya or to his son Tamīm (d. 501/1108), but it was probably compiled within the entourage of their court and dedicated to them. Three different recensions of the work have been identified by Armin Schopen on the basis of the additional chapters juxtaposed with the section on ink making. ${ }^{20}$ Nonetheless, the number and the typology of recipes for ink making varies according to the different recensions; ferrogallic and mixed inks are largely favoured in the modern recensions, while the number of carbon inks is higher in the oldest one. ${ }^{21}$

The part of the 'Umdat al-kuttāb related to ink production was explicitly mentioned as the basis of another treatise entitled Al-muhtara' fi funūn min al-suna' ('The findings on the techniques of craftsmanship'), by al-Malik al-Muzaffar Yūsuf al-Ġassānī (m. 694/1294), the Rasulid sultan of Yemen. Four witnesses to Al-muhtara are known and an edition has been published. ${ }^{22}$ The clearest difference between $\mathrm{Al}$-muhtara ${ }^{c}$ and the Tunisian work is that, besides the chapters on the book arts (which, as anticipated, roughly reflects the Umdat al-kuttāb), the Al-muhtara contains sections on martial arts, in particular

18 Al-Rāzī also included a recipe for an invisible ink in his Kitāb al-ḩawāṣṣ; see Raggetti, "Cum Grano Salis" (cit. note 9), p. 325.

19 The reference edition here is al-Mu'izz Ibn Bādīs, "Umdat al-kuttāb wa-'uddat dawī al-albāb," edited by 'Abd al-Sattār al-Ḥalwağī and 'Alī 'Abd al-Muhsin Zakī, Mağalla machad al-mahtūtạt al-arabiyya, 1971, 17: 43-172. For the witnesses and other editions available, see Schopen, Tinten und Tuschen (cit. note 4), pp. 28-32.

$20 \quad$ Ibid.

21 Colini, From recipes (cit. note 3), p. 36.

22 Al-Malik al-Muẓaffar Yūsuf b. 'Umar b. 'Alī b. Rasūl, Al-muhtara' fi funūn min al-șuna', edited by Muhammad đĪsà Șāliḥiyya, (Kuwayt: Mu’assasat al-širāc al-'arabī, 1989). 
on the construction of weapons such as the catapult and other battlefield furnishings. These sections are oddly juxtaposed with the art of book binding, in addition to chapters on fabric dyeing and stain removal, the production of soap and gold- and silver plating.

A less studied work is the treatise Kitāb al-azhārfí 'amal al-ậbār ('The most beautiful flowers on the production of inks'), by Muhammad Ibn Maymūn al-Marrākušĩ al-Hiimyarī, (mid-13th century). The only witness known to date is an autograph dated 649/1251-2 and compiled by the author during his stay in the madrasa al-Mustanșiriyya in Baġdād. ${ }^{23}$ Another autograph preserved in the Bibliotheque Nationale de France (MS Paris BnF Ar. 6915) attests to the author's competence in the field of alchemy. Unfortunately, of the 27 chapters listed in the introduction of the Kitāb al-azhār, only six are actually compiled, after which the author stops writing, consumed by an emotional crisis due to an unrequited love. The topics covered in his treatise are limited to the preparation of different types of liquid and dried black inks and coloured inks. ${ }^{24}$

The last work for the period to be considered is the Tuhaf al-hawasss fi țuraf al-hawāss ('The gifts of the wise men on the curiosities of the substances') by Abū Bakr Muhammad b. Muḥammad al-Qalalūsī (m. 607-707/1210-1307), an Andalusian scholar mentioned in different bibliographical repertoires; he was an authority in the field of Arabic language and a poet. In the introduction to his treatise, he dedicates it to a kattib, a chancellor who worked at the Nasrid court of Granada. There are currently two known witnesses to this work (one in Rabat, the other in the National Library in Paris) according to which an Arab edition was published in 2007. ${ }^{25}$ The two witnesses present a different sub-division of the text: the one kept in Rabat is divided into three chapters

23 It has been published as a photostatic reproduction, introduced by Ibrāhīm Šabbūḥ: Muhammad b. Maymūn b. 'Imrān al-Marrākušĩ, "Kitāb al-azhār fĩ 'amal al-aḥbār li-Muḥammad b. Maymūn b. 'Imrān al-Marrākušī (al-qarn al-sābi' al-hiğrī)," Mağallat ta'rīh al-'ulüm al-'arabiyya wa-l-islämiyya = Zeitschrift für Geschichte der Arabisch-Islamischen Wissenschaften, 1422/2001, 14:41-133 (Arabic pagination).

24 According to the initial index, the missing essays would have been dedicated to: metallic inks, also those for writing on metal surfaces; the plating of various materials; the decoration of the hands with special dyes; the combination of the various pigments; the variations of writing colours over time; possible gilding surrogates; invisible inks; the removal of stains and erasing writing from writing supports; the method for breaking and restoring seals; different treatments of paper; the manufacture of the liqa (the felt pad on the lip of the inkwell); as well as a couple of sections dedicated to iron manufacture and to the annealing of swords and knives and a section dedicated to stain removal. There is also the title of a section dedicated to theoretical speculations about the rational scientific method. Al-Marrākušī, Kitāb al-azhār (cit. note 23), pp. 67-70.

25 Abū Bakr Muhammad b. Muḥammad b. Idrīs al-Quḍāī al-Qalalūsī, Tuhaf al-hawāṣs fì țuraf al-hawāṣṣ, edited by Ḥusām Aḥmad Muhtāar al-'Abbādī (al-Iskandariyya: Bibliotheca Alexandrina, 2007). 
concerning, respectively: ink making; ink and stain removal from different surfaces; the use of ink on solid metals, dyes and paints. The Paris witness, by contrast, is divided into two chapters, the first concerning the preparation of inks, the second the removal of stains.

\section{4}

\section{Approach to the Texts and to Their Transmission}

The intellectual approach to this kind of textual production, equally well established in the Western literary tradition, was primarily based on the technical content that the sources are thought to deliver. ${ }^{26}$ According to the approach of the 18th-century Italian erudition and then expanded throughout Europe, the technical sources were essentially considered a guide containing practical instructions that could be interpreted and reproduced through the identification of the chemical components of the materials employed. From the 19th c., the study of these testimonies of artistic practices aimed at the restoration of ancient artefacts with the intention to repair or integrate the original objects in a completely mimetic style. Today, the approach to restoration has, of course, changed radically and is now aiming at safeguarding the conservation of objects through the employment of reversible products and recognizable integration techniques without cancelling the stratifications and the traces of their material history. It is only in recent decades that the dissolution of the traditional functional interpretation of these sources, which anchored them to the technical information they preserve, opened up a wider, multidisciplinary approach that allows for appreciation of their wider cultural significance. The traditional assumption according to which textual sources related to technical crafts would have represented the most reliable proof of the practices and the materials employed by artists at the time these treatises were compiled, has been questioned on the basis of textual and philological considerations. ${ }^{27}$ This open attitude towards such literary productions allows us to investigate the idea of what was intended to be transmitted, by whom and to whom, their knowledge and competences, and the cultural and social contexts within which these texts circulated.

26 Simona Rinaldi, "Per una filologia dei trattati e ricettari di colori," Studi di Memofonte, 2016, 16:1-16.

27 Sandro Baroni, Paola Travaglio, "Considerazioni e proposte per una metodologia di analisi dei ricettari di tecniche dell'arte e dell'artigianato. Note per una lettura e interpretazione," Studi di Memofonte, 2016, 16:25-83. 
Such literary productions, namely technical treatises in the guise of compilations of recipes, are usually subject to fluid transmission, reflected in the presence of different recensions and branches of transmission of each work. The structure of the texts, arranged as a juxtaposition of different textual units relating to specific technical procedures fosters the production of variants at different levels - i.e. in the number and selection of the recipes, in the macrostructure of the treatise and the arrangement of the recipes, but also within single recipes - depending on the different skill levels of their copyists or compilers. An analysis of the available sources reveals that the textual units (recipes) or groups of units often transcended the boundaries of a specific textual tradition and were included in later compilations. In fact, in the classical Arabo-Islamic literary context, as in other pre-modern literary contexts, the concept of authorship was very blurred, and quotations from previous sources were common and not exclusive to treatises composed as recipe collections. ${ }^{28}$ Thus, in addition to the essential and desirable critical editions of the works in question, a comparative textual analysis is crucial. ${ }^{29}$ In a wider perspective, this comparison should not be limited to the treatises in the Arabic language, but should also include other historical and cultural contexts, as suggested by the evident echoes of late antique and early medieval sources found in the treatises under study. ${ }^{30}$

As mentioned above, the roles of author, compiler and copyist seem to intertwine and cross each other in the different phases of transmission of this technical material, contributing to very fluid and elastic traditions in which the number of recipes and their organization is not stable. ${ }^{31}$ The identification of the authorial components of each work and their distinction from editorial or compilatory elements is crucial for a correct interpretation of these kinds of sources, not only to investigate the mechanisms of their formation and transmission, but also to evaluate the technical content elaborated and delivered by every author.

28 Sandro Baroni, "Ricettari: struttura del testo e retorica," Studi di Memofonte, 2016, 16:90113 , p. 9 o.

29 Sound critical editions of these fluid and unstable traditions are challenging to establish. For an exemplar critical edition of an Arabic compilation of recipes, see Raggetti, $\bar{I} s \bar{a} i b n$ Alìs Book (cit. note 4).

30 Parallels with the Western tradition can be found both in textual procedural elements as well as in the structure of the compilations themselves and in the different subjects juxtaposed with sections on colour/ink making. Fani, Le arti del libro (cit. note 1), pp. 175-180. Cf. Baroni, Travaglio, "Considerazioni" (cit. note 27), pp. 26-27.

$31 \quad$ Ibid., pp. 30-31. 
A fruitful preliminary consideration focused on the supposed competence of the alleged authors, informed by the available biographical data, by what they declared in the introductions to their works and, finally, by the actual technical content they transmit. The analysis thus includes both the macrostructure of the works (the treatises' 'narrative' organization) and their microstructures (i.e. the recipe units).

The high number of recipes transmitted by each work, and the juxtaposition of rather different subjects, such as ink making, bookbinding, paper making, but also stain removal, fabric dyeing, soap making and even the production of battlefield equipment and weapons, makes attribution to a single author at least questionable. The cases of the treatises ascribed to the Zirid ruler al-Mu'izz Ibn Bādīs and to the Rasulid al-Malik al-Muẓaffar are quite emblematic. ${ }^{32}$ If, on the one hand, it is difficult to imagine that rulers could dominate such different sorts of crafts with such technical competence, and that they had the time to collect all these materials, then, on the other hand, their position would certainly have facilitated their access to written sources in the libraries of their palaces and their oral communication with experts. At the same time, the introductions to the two works attest explicitly to their compilatory nature. The ascription to the two rulers can be reasonably read as an act of deference by one of the 'alim of their entourages. Moreover, the Rasulid ruler, or whoever compiled the treatises on his behalf, explicitly mentions Ibn Bādīs (referring to him as șăhib al-Mahdiyya, 'the governor of al-Mahdiyya') as a source for the part of his treatise related to ink making.

The well-attested biographical and scientific profiles of al-Rāzī and al-Marrākušì certainly grant them a presumed higher degree of competence as alchemists and physicians, two fields that share with ink making common a knowledge related to the transformation of natural elements. Even in these cases, however, and in particular in relation to al-Marrākušì, the high number of recipes transmitted, sometimes very similar to each other, strongly suggests a possible, at least partial, compilatory nature of his work. At the same time, the Kitāb al-azhār, more than the others, appears to be a text closely related to a real operative context, as attested by the arrangement of the recipes according

32 It is worth mentioning that other works are ascribed to these two rulers, attesting to their possible competence in different fields of sciences, but also a possible common practice for the attribution of literary and technical works of interest to rulers; Fani, Le arti del libro (cit. note 1), pp. 155-164. 
to the process used in the treatment of ingredients and by the numerous interventions of the author in terms of practical advice. ${ }^{33}$

The organization of the treatises and the categories in which the inks are included are very interesting both from the perspective of assessing the authors' competence and for understanding the modalities of transmission of these texts. The deconstruction of these texts at different levels, from the chapters and sub-chapters to single recipes, enhances our understanding of their origin and allows us to identify, at least in some cases, the sources from which they developed. At the same time, it reveals their specific peculiarities and the cultural context to which they refer. As for the classification of the inks, the basic structure of the recipe usually includes a short title, which may refer to different aspects of the product obtained or to its manufacture. ${ }^{34}$ Nonetheless, it is worth underlining that rubricated titles were commonly added after the copy of the text, in blank spaces left by the scribes and in some cases filled in by someone else. This practice may have resulted in a lack of consistency between the title and the content of the recipe, with the titles changing or shifting from one recipe to another during the various stages of copying. For this reason, it is misleading to consider inconsistences between the title of a recipe and its content as a crucial proof of an authors' lack of competence on the subject. A general distinction is usually made between carbon inks (traditionally defined as midād), iron-gall inks (hibr) and mixed ink (midād/hibr murakkab), all encompassing both black and coloured inks. ${ }^{35}$ An additional category common to the treatises is that of the coloured inks or paints (liqqa), which were possibly employed by tapping the felt or silk pad or tuft of cotton on the lip of the inkwell, to which the term refers. ${ }^{36}$ As previously mentioned, the degree of coherence between the definition given in the titles and the actual product described in the text could have been subject to changes made during the history of the text's transmission and is not necessarily an authorial responsibility. A meaningful example is represented by al-Qalalūsì's treatise in which the product of every recipe is designated in the title as midād, notwithstanding the actual ingredients and the ink obtained. Interestingly, al-Qalalūsī

33 Fani, Le arti del libro (cit. note 1), pp. 171-172.

34 See infra, p. $115^{-116 .}$

35 Cf. Ibrāhīm Šabbūḥ, "Maṣdarāni ğadīdāni 'an șinā'at al-mahụụụt: hawla funūn tarkīb al-midād" Dirāsāt al-mahtūṭ̂̄t al-Islāmiyya bayna itibārāt al-mādda wa-l-bašar: a'mal al-mu’tamar al-tān̄ì li-Mủassasat al-Furqān li-l-Turāt al-Islāmī, 1314 / 1993, edited by Rašīd al-'Inānī (London: Mu’assasat al-Furqān li-l-Turāt al-Islāmī, 1417/1997):15-34, p. 23.

36 For a description of these categories, see Colini, From Recipes (cit. note 3), pp. 17-22. In the treatises, the term liqa indicates coloured inks without gall nuts (sometimes also called midād), for which a more common employment using the tuft or pad can be assumed. 
also labels the recipes belonging to other traditions, such as those explicitly ascribed to al-Rāzī and those defined as hibr in the Zinat al-kataba, as midād. ${ }^{37}$

As mentioned, in some cases, i.e. al-Rāzī's recipes included in al-Qalalūsì's work, it is the title of the recipe itself that allows us to trace the previous source. Only some of them are attested in the unique witness we have of the work Zinat al-kataba, suggesting the idea that it could be an excerpt of a wider text. In general, we cannot automatically assume that the characters mentioned in the headings have produced literary works including ink recipes. It is also possible that these personalities transmitted the recipe orally, or that the ink described was associated to their names because they used to prepare it for their personal use - in this case, the description of the procedure could have been transmitted by someone else - or even that a pseudo-epigraphic attribution was made to an authoritative source. It is therefore misleading to think that every reference to famous personalities appearing in the titles of single recipes testifies to these people inventing or transmitting them in a written form without supplementary confirmation in the textual traditions. ${ }^{38}$

Redactional Interventions

If the authorial and original nature of the compilations can be supported by some of the mentioned elements related to the macrostructure of the treatises (i.e. authorial introductions to the texts and the systematic organization of the recipes according to different criteria), other textual elements at a micro-level of analysis could contribute to the identification of their compilatory additions and redactional extensions. ${ }^{39}$ In this case, we consider an "authorial" or "original" compilation to be a set of recipes that have been described and transmitted by someone according to his personal thinking and with his own original writing, on the base of a direct observation or experience of the procedures, or after having obtained them via oral or written transmission. ${ }^{40}$ This is testified at a formal and microstructural level by recipes with very similar syntactical structure, where the vocabulary is extremely reduced and repetitive. The

37 al-Qalalūsī, Tuḥaf al-hawāșș (cit. note 25), pp. 21-22, 23-24; Fani, Le arti del libro (cit. note 1), pp. 172-173 (recipes Q I.4, 5, 11). It is not possible to establish at what point during the transmission of this text the lexical change occurred, but it is possible that the change was made on the basis of a different use and perception of these technical terms in the peripheral region of al-Andalus.

38 Cf. Šabbūḥ, Maṣdarāni ğadīdāni (cit. note 35), p. 22.

39 Baroni, Travaglio, Considerazioni (cit. note 27), p. 31.

40 Ibid., p. 30. 
authorship can refer to the entire compilation or to a certain core of recipes to which other material has been added drawing from other written sources.

\subsection{Syntactical Structure}

Regarding the lexical aspect of the treatise, a couple of examples show how the presence of dialectal terms can help in the identification of the authorial recipes. The first case is represented by al-Malik al-Muzaffar's treatise. As mentioned above, the 'Umdat al-kuttāb is the explicitly mentioned source of the Yemeni work for the part related to ink making. Of the 28 recipes for carbon inks in the Tunisian treatise, only six are included in Al-muhtara, one of which proves to be original, at least in its textual dimension, and is characterized by the use of a Yemeni dialectal term to indicate sesame oil (salit t), not mentioned in other sources. ${ }^{41}$ In the same way, the Andalusian al-Qalalūsì also introduces the dialectal name of a plant to obtain a red pigment: the riğl al-hamām, ('leg of the dove'), to indicate the Anchusa tinctoria L., the use of which is not mentioned in other treatises. ${ }^{42}$

Regarding the syntactical structure of the recipes, there are no apparent discrepancies among the different works. The most common scheme is scanty and characterized by a set of textual elements referring to the definition of the product, the name of the ingredients and their quantity, the different procedural phases with additional specification about the modalities, duration, place of the operations etc., and finally the result or the indication of the use of the product, as shown by the example in the following chart:43

Title (MM II.18)

Starting verb I ("to take")

Specification of quantity I

Ingredient I

Operation I (verb)

Specification of place

Operation II (verb)

Specification of quantity (II)

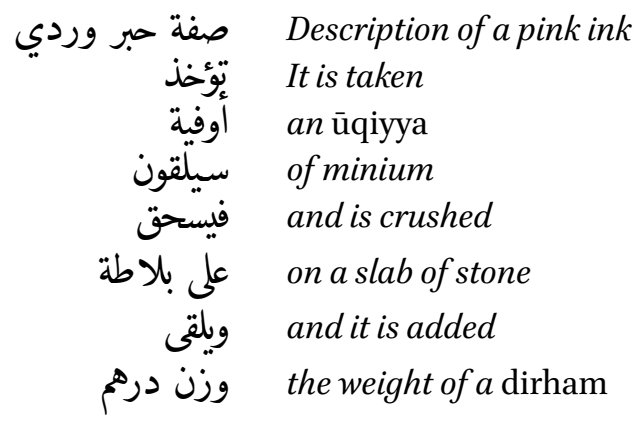

41 In fact, the recipe transmitted is a carbon ink obtained from the soot of sesame oil, which was quite common in other Arab treatises and is described as an Egyptian ink. Al-Malik al-Muz̧affar, Al-muhtara' (cit. note 22), p. 70; Fani, Le arti del libro (cit. note 1), pp. 59, 169 (recipe мм II.6).

42 al-Qalalūsī, Tuḥaf al-ḩawāṣṣ (cit. note 25), p. 28; Fani, Le arti del libro (cit. note 1), pp. 146, 189 (recipe Q II.4).

43 Al-Malik al-Muzaffar, Al-muhtara' (cit. note 22), p. 76. 
Ingredient II

Specification of quantity III

Ingredient II I

Operation III (verb)

Specification of mode

Ingredient IV

Result and use

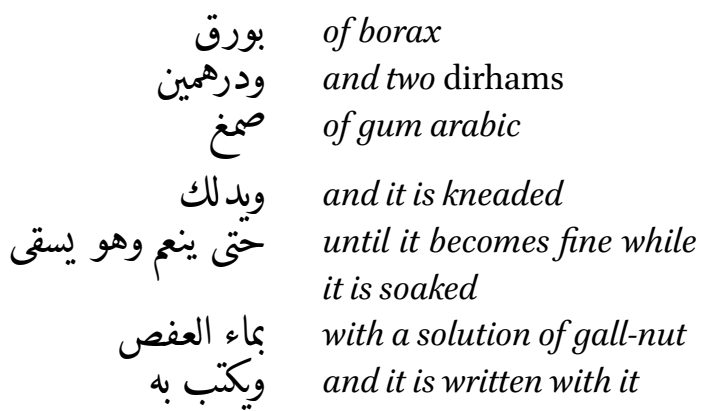

\subsection{Lexical Elements}

Apart from the few examples of dialectal terms employed, the vocabulary of the recipes is quite repetitive across the different traditions; this is true not only for the names of the ingredients, but also for the procedural verbs used in the sources. They can appear both in the jussive form and in an impersonal form (expressed by the use of a passive form); the alternation is quite frequent not only within a single work, but also within the same recipe, thus the shift does not seem to be related to the interpolation of recipes from different textual traditions. Moreover, operations aimed at a more formal homogeneity of the material gathered in a compilation of recipes can also be undertaken by the compilers or copyists. If this can be considered a rather passive intervention, affecting only the formal dimension of the recipes, in other cases the scanty and telegraphic structure of a recipe can also be affected by substantial redactional interventions or rewriting, which expand and/or transform the original formulation of the technical procedure. Editorial interventions of this kind can occur not only within a single textual tradition in the process of copying the work, but also in the transmission of textual units from one tradition to another, so that the same recipe, or better, the common origin of different recipes, sometimes becomes barely recognisable. ${ }^{44}$ The example shown in the Appendix is meaningful in two respects: one the one hand, it shows that the later authors should know al-Rāzì's treatises; on the other hand, it gives a sound idea of the competences of the person who intervened in the original recipe. ${ }^{45}$

\subsection{Organization of the Compilations}

In addition to the modifications to the text of single recipes, the works emerging from an editorial or redactional process can show interventions in the

\footnotetext{
44 See Appendix.

45 Sometimes, additional phrases attesting to the utility or the effectiveness of a procedure represent mere literary topoi; take, for example, the word muğarrab. Cf. Raggetti, ' $\bar{I} s \bar{a} i b n$ 'Alı's Book (cit. note 4), pp. xv-xvi.
} 
macrostructure of the collection, when the order of the recipes is adapted to the editor's different consecutio. The classifications and categories of inks attested in the sources available are expressed alternatively in the title of the recipes or in the headings of chapters or sub-chapters in which the recipes are included, and referred to:

- the colour of the products obtained (black, different colours, metallic, invisible);

- their composition (hibr/iron-gall inks, midād/carbon inks, murakkab/ mixed);

- their final state (liquid, solid, powder);

- their preparation (under the sun, on the fire, in the shadow, by infusion, by decoction, by maceration)

- their final employment (with reference to the writing support, to the texts to which their use is dedicated, to the application implement, for example the lìqa);

- the famous historical characters and scholars who used / transmitted the recipe.

Theoretically, any recipe can be integrated in one or more of these categories simultaneously; thus, it is common for an author who extrapolates recipes from a previous source to insert it into the appropriate category of his own work. In the Kitāb al-azhār, for example, al-Marrākuši had to adjust the order of the recipes derived from al-Rāzì's and Ibn Bādīs's works so that it was compatible with his highly original scheme arranged according to the method of preparation and manipulation of the ingredients. ${ }^{46}$

While in certain cases the inclusion of recipes from previous sources is made explicit in the text itself — for example in Al-muhtara' fífunūn — ${ }^{47}$ or in the titles of the recipes, in other cases, only comparative analysis can clarify the phenomenon and identify the hypothetical original/authorial version of textual units or, better put, the first occurrence in written sources of this specific linguistic context. ${ }^{48}$

46 Cf. supra, note 24.

47 Cf. supra, p. 110, 114.

48 The recipes can be considered original only on the basis of the available sources, but they are certainly a much smaller number of what has been written. In any case, possible syntactical or lexical discontinuity in what is considered to be the original nucleus of a work, or possible historical or regional elements attesting a more ancient origin of a recipe within that core, or a geographic origin different from that of its alleged author, should hint at a derivation from a different textual tradition. 


\subsection{Explanatory Additions}

Another common redactional intervention in the treatises studied is the addition of errant phrases or explanations of difficult passages in recipes derived from different traditions; a meaningful example is the note added by al-Marrākuši to the margin of his treatise, in correspondence of one of the recipes ascribed to al-Rāzì. The note refers to the word istār, a unit of measure not previously mentioned in other treatises and that evidently required the equivalence to the system more commonly used in Bagidād. ${ }^{49}$ In another case, the same al-Marrākušì made a redactional intervention in the transmission of a recipe ascribed to Ibn Buhtīšú ${ }^{c}$ and also mentioned in al-Rāzī and in al-Qalalūsī treatises, in the latter with an explicit attribution to the same al-Rāzī. ${ }^{50}$ In this case, al-Marrākušì changes the unit of weight measurement attested in the other two treatises, i.e. mikyāl, replacing it with a proportional system of parts. This was probably done to avoid confusion with the mention of an uncommon reference system. ${ }^{51}$

\subsection{Modalities of Formation}

More broadly, these phenomena can give us an idea of the modalities of formation of these kinds of collections. In fact, the texts can be extended in various aggregative ways, or, on the contrary, can be reduced, contracted or deconstructed and rearranged. And, even if, generally, in this kind of production "sobriety is almost always primitive," 52 a comparison of the texts reveal a more elastic dynamic in the history of their transmission. Just to make some examples, the 11th-century treatise 'Umdat al-kuttāb, appears to be the richest for number of recipes transmitted (approximately 150), despite its antiquity. At the same time, if we focus on the text of single recipes, like the one presented in the Appendix, the 13th-century treatise Kitāb al-azhār presents an expanded version of the material derived from previous sources. Nevertheless, its almost

49 The note reads: "al-Marrākušì says, God bless him: there are 40 istār in the mann of Bag̉dād."; al-Marrākušī, Kitāb al-azhār (cit. note 23), p. 75 .

50 Ibid., p. 80; al-Rāzī, Zìnat al-kataba (cit. note 17), pp. 225-226; al-Qalalūsī, Tuhaf al-hawāasṣs (cit. note 25), p. 21. The reference is to the famous family of Persian physicians who worked between the 7 th and the 9th centuries; they all came from the Gundishapur Academy and some of them became personal physicians to the Abbasid caliphs; see Dominique Sourdel, "Bukhtīshū'," in Encyclopaedia of Islam, New Edition (cit. note 5), vol. I p. 1298. Armin Schopen suggests the identification with Ğibrīl Ibn Buhtî̌šū's, see Schopen, Tinten und Tuschen (cit. note 4), p. 89 .

51 For an excursus on the units of measure used in the treatises under study, see Fani, Le arti del libro (cit. note 1), pp. 186-187.

$5^{2}$ Baroni, Travaglio, Considerazioni (cit. note 27), p. 33 . 
contemporary treatise, the Yemeni Al-muhtara'fi funün min al-șun'a and the Andalusian Tuhaf al-hawāșs fi țuraf al-hawāṣș, presents a much scantier version of the same units.

The modalities of formation of this kind have been identified following the study of Western treatises on colour making and can easily be adapted to treatises in the Arabic language. ${ }^{53}$ Among the modalities of expansion of texts, the most common process of aggregation in our treatises is the interpolation of selected recipes from different sources based on the different categories of inks elaborated by every author. This aggregative system is also reflected in the titles of the recipes and they are often introduced using the heading sifa uhrà (another description), or similar phrases, following a more precise definition of the first recipe of a set. Only in the case of invisible inks is it possible to recognize a thematic aggregation in almost all the sources at our disposal. ${ }^{54}$ The set of recipes "to put secrets in the books" (wada'al-asrär fíal-kutub), as they are generally described by the sources, is already attested in the more ancient treatise, the Zinat al-kataba by al-Rāzī, and it is mentioned in all the subsequent compilations, even if the recipes do not appear exactly in the same order within the set.

A final consideration will focus on the introductions to these works. If, on the one hand, they frequently refer to the circumstances of their composition, revealing important clues about the real technical competence of the authors/ compilers, they provide evidence of a literary dimension and of their intellectual framework. The presence of rhetorical elements in the introductions has been underlined and categorized based on previously conducted studies of specific Western treatises. ${ }^{55}$ The same categories and rhetorical elements typical of literary works can be identified in the introductions to the Arabic treatises, demonstrating a common cultural philosophical background. The specific constitutive elements have been reapplied by Sandro Baroni to the

$53 \quad$ Ibid., pp. 33-52.

54 In the Kitāb al-azhār, the chapter on invisible inks is not developed, despite being announced by the author in the initial index; cf. supra, note 24 .

55 Maite Rossi, "Il pensiero e il colore. Modelli della filosofia classica nella letteratura tecnico-artistica medievale," Quaderni dell'Abbazia. Fondazione Abbatia Sancte Marie di Morimundo e Museo dell'Abbazia di Morimondo, 2008, 15:161-192. 
common rhetoric scheme of the Aristotelian exordium. ${ }^{56}$ This can be summarized as:

- Prótasi: self-presentation - declaration of intent / recipient / subject;

- Invocatio: invocations to the divinity - theological references - invocation to the dedicatee;

- Captatio: statements of humility - reference to an authority — declaration of simplicity / truthfulness / experience.

Below is a sample of the introduction from the Zinat al-kataba that highlights the constituent rhetorical elements: ${ }^{57}$

Invocation to the divinity In the name of God, the most Gracious, the most Merciful

Subject

This is the book, the adornment of the scribes and what they cannot live without.

Declaration of intent It can happen that [the content of] one of its chapand declaration of utility ters is needed [by someone] with no proficiency in the subject, so the resulting damage is big and the $k a \bar{t} i b$ is discredited.

Theologicalreference We have therefore put together what this book consists of, "and above every person of knowledge, there is one more learned" [Qur. XII: 76].

The same elements can be identified in thelonger introduction of al-Marrākušı̀s work. ${ }^{58}$ In this regard, Baroni underlines that Aristotle supports an indirect proportionality between the elaboration and length of this part of the speech and the technical competence of the audience, stating that a proemio or exordium introducing the subject is not necessary for a competent public. ${ }^{59}$

\section{$8 \quad$ Conclusions}

To conclude, according to a multi-level analysis, exemplified here by specific case studies, the sources under investigation appear to provide much more information than the procedural indication for ink production. As we

56 Baroni, Ricettari (cit. note 28), p. 104.

57 Cf. the Arabic text in al-Rāzī, Zinnat al-kataba (cit. note 17), p. 222.

$5^{8}$ Cf. Fani, Le arti del libro (cit. note 1), pp. 8o-81, 157-16o.

59 Baroni, Ricettari (cit. note 28), pp. 104-10; see also, Roland Barthes, La retorica antica (Milano: Bompiani, 1972), pp. 91-92. 
have tried to demonstrate, their technical content as well as their structure and organization at a micro- and macro-level, clearly refer to well-established traditions and theoretical paradigms, which must be recognised in order to interpret the written expression of this professional knowledge. As Sandro Baroni writes: ${ }^{60}$

The technical literature related to the arts is certainly the reflection of a practical knowledge in constant updating, but we must not forget that the literary texts that transmit this knowledge present all the problems originated by the distance between the word and the practice. They are submitted to expository and organizational methods of the "technical report," which are sometimes able to alter and distort the mere operative procedures, but at the same time contain further information about the generative context of the technical contents.

In other words, the sources presented here reflect the social history of the communities within which they were produced. Their organization, their technical content and the literary topoi are crucial elements requiring specific attention and interpretation in a comparative perspective.

Within the Arabic literary tradition, these treatises are located in the broad category of adab literature, in which the didactical or technical content of a text not only aims to instruct, but also to educate, in a wider sense, the literate class of the kuttā $b$ and to show the knowledge available in that particular field. ${ }^{61}$ The fact that, in some cases, these treatises could have been used as a guide for ink making by scribes or craftsmen in ink makers' workshops is plausible and undeniable, but the intention that animated these compilations certainly goes beyond the didactical and technical purpose of manuals or handbooks.

\section{Appendix}

R Abū Bakr Muḥammad b. Zakariyyā’ al-Rāzī (d. 313/925), Zìnat al-kataba

IB al-Mu'izz Ibn Bādīs al-Ṣanhāḡōi (d. 454/1061), 'Umdat al-kuttāb wa-'uddat dawwī al-albāb

M M al-Malik al-Muẓaffar Yūsuf al-Ġassānī (d. 694/1294), Al-muhtara' fi funūn min al-șunac

6o Ibid., p. 106 (the English translation is mine).

61 Fani, Le arti del libro (cit. note 1), pp. 191-193. 
Ṃ̣ Muhammad b. Maymūn b. 'Imrān al-Marrākušì (fl. 649/1251-2), Kitāb al-azhār fì 'amal al-ahbāor

Q Abū Bakr Muḥammad al-Qalalūsī (d. 707/1307), Tuḥaf al-ḩawāṣs fi țuraf al-h̆awāṣs

$\mathbf{R}^{\mathbf{a}}$

$$
\mathbf{I} \mathbf{B}=\mathbf{M} \mathbf{M}^{\mathbf{b}}
$$

Mب̣ $^{\text {c }}$

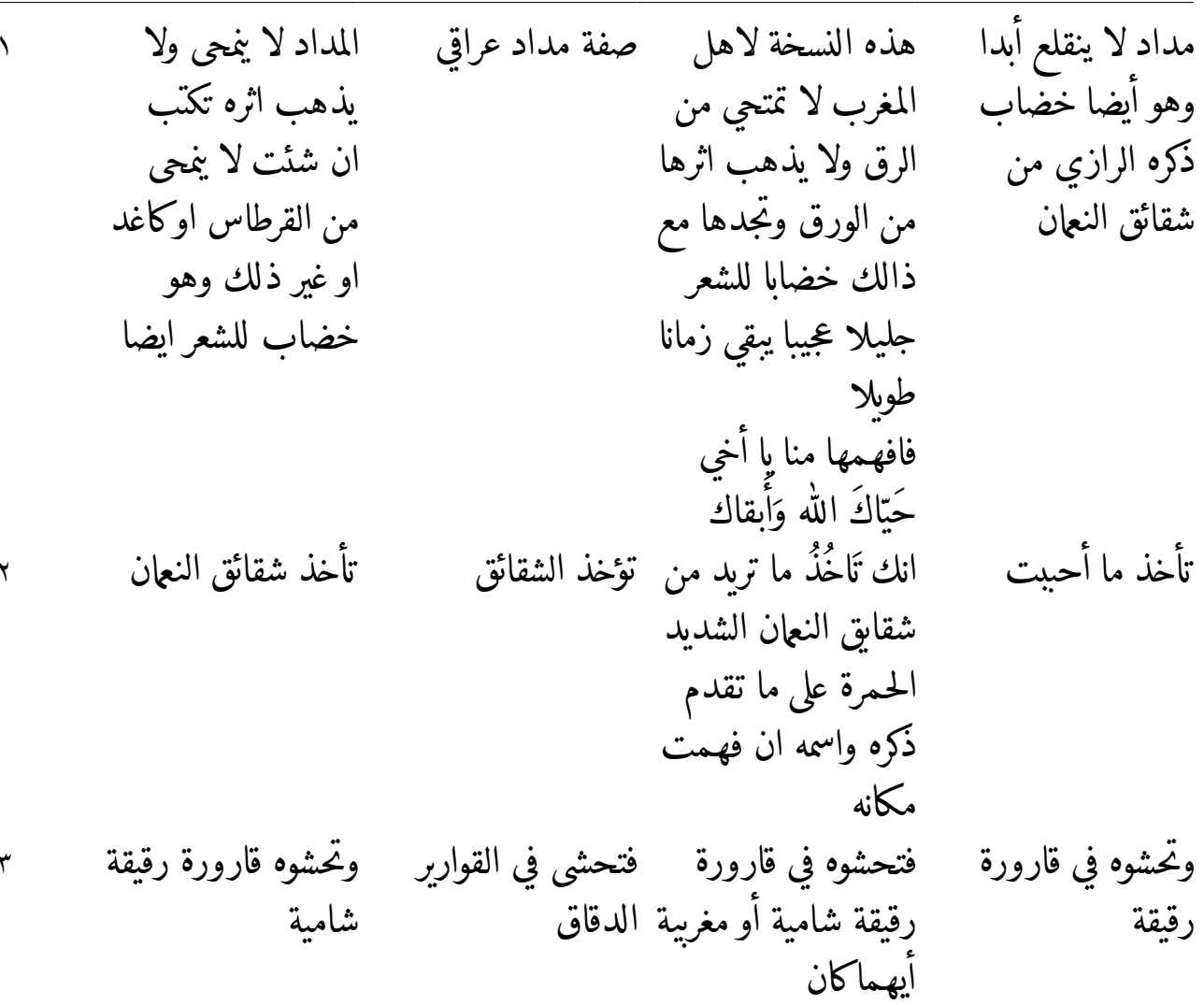

a Al-Rāzī, Zìnat al-kataba (cit. note 17), pp. 222-223.

b Ibn Bādīs, 'Umdat al-kuttāb (cit. note 19), pp. 82-83; al-Malik al-Muzaffar, Al-muhtara' (cit. note 22), pp. 68-69.

c Al-Marrākušī, Kitāb al-azhār (cit. note 23), pp. 106-107.

d Al-QQalalūsī, Tuhafal-hawāṣṣ (cit. note 25), p. 25. 
(cont.)

$\mathbf{R}$

$\mathbf{I B}=\mathbf{M M}$

M ̣̣

Q

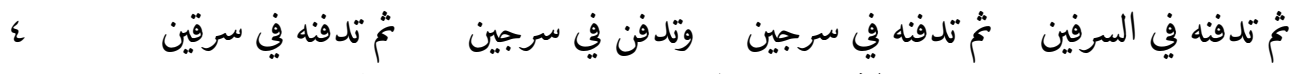
رب

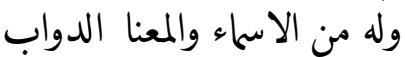

واحد في كبنا المتقدّم

ذكرها الموسومة فينة

بالحكة السرقين

والسرفين وبطون

الحيل والطبيعة تخدم

الطبيعة والنار الحايلة

فافهمها من المرّاكثي

هنا وهناك ويكون

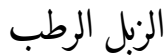

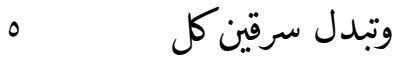

وتبدل السرفين كل وتبدّل له الزبل الرطب

ثلاث ايام

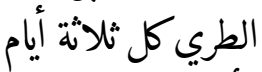

ثلاثة أيام

وأنت تعتبره بعد ذلك نك الك الك

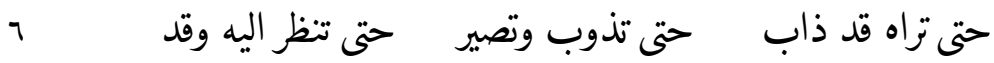

حتى تنظر إليه وقد ذاب وصار ماء

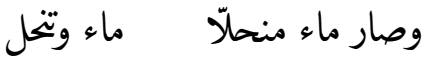

ذاب وصار ماء

وانحل

v وآكتب به حيث شئت

ثم آكتب به حيث وهينئن تكتب به

حيث شيت فيا ذكرنا

شيت

$\wedge$

فلا ينحى

فإنه لا يمتحى جملة

فإنه لا يمحي

واحدة

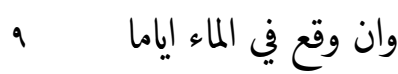

وإن دفع في الماء أياما ولن تقيى القرطاس المكتوب به في الماء

أياما على ما ذُكر

والسلام 


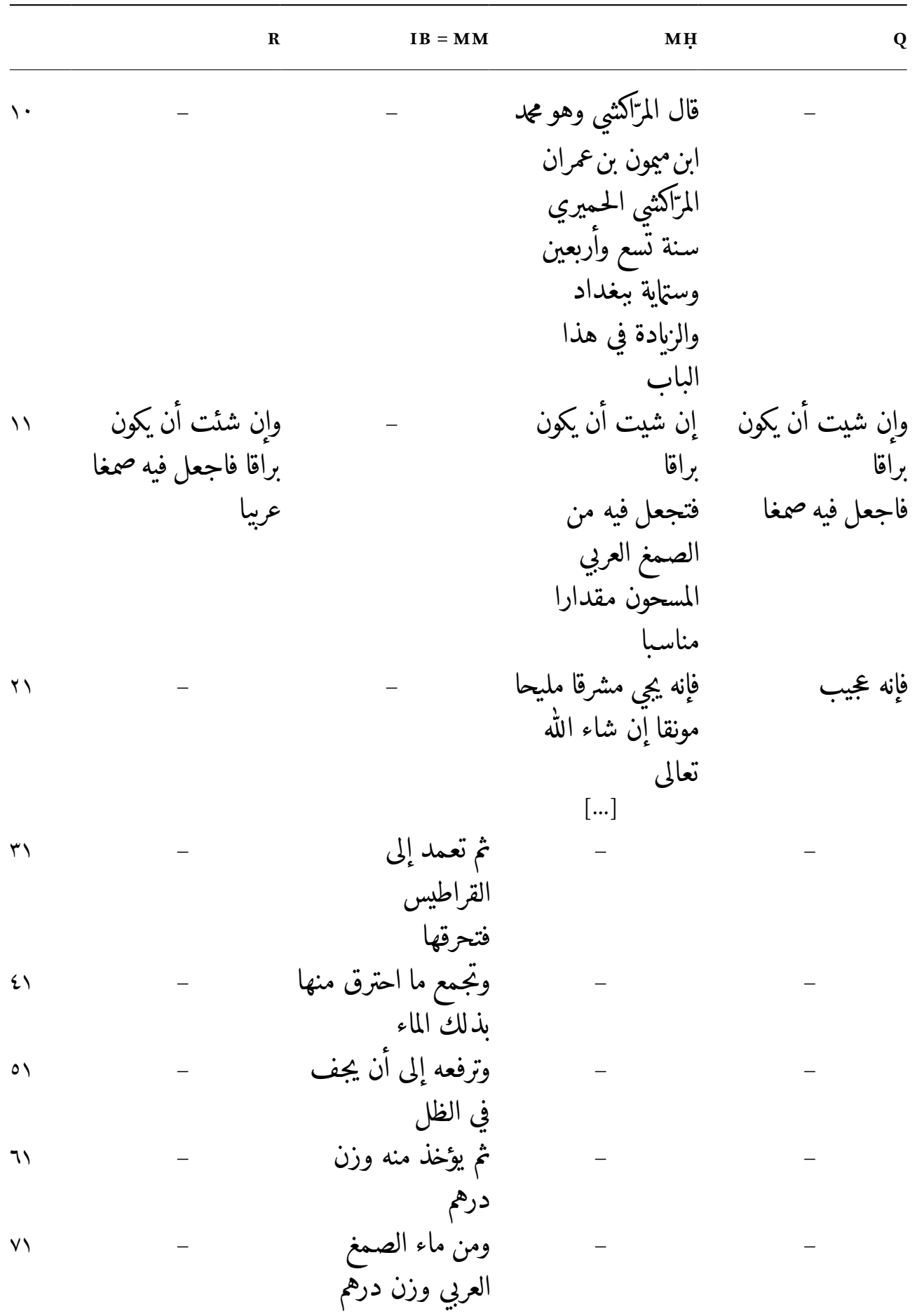


(cont.)

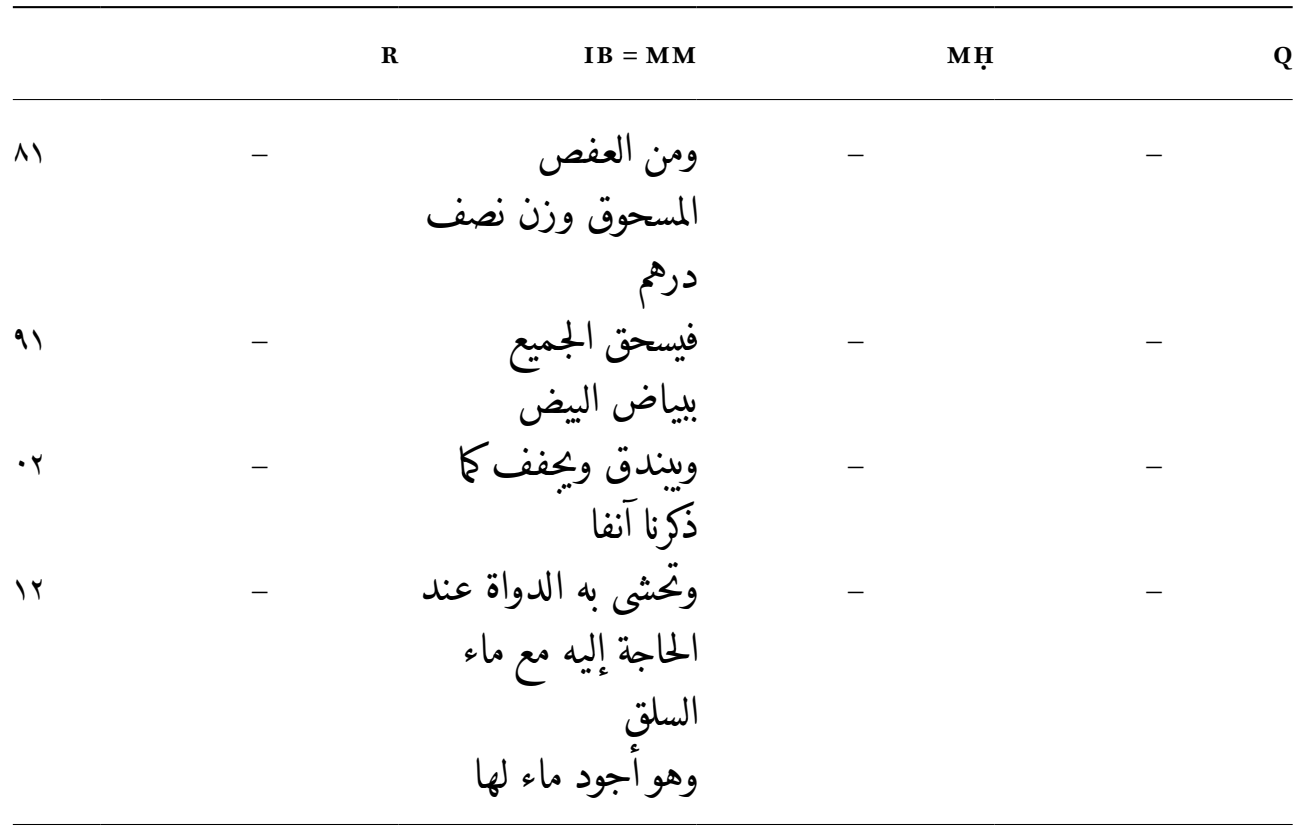

\begin{tabular}{|c|c|c|c|}
\hline $\mathbf{R}$ & $\mathbf{I B}=\mathbf{M} \mathbf{M}$ & Mழ̣ & Q \\
\hline
\end{tabular}

An ink that doesn't Description of an fade and whose Iraqi ink. traces don't disappear; if you want, write, and it will not fade on the papyrus, or paper, or other material; it is also a dye for the hair.
This copy is of the people of Maghreb; it doesn't fade from the parchment and its traces don't disappear from the paper. You will discover that it is a beautiful and marvellous dye for the hair that lasts for a long time.

Learn it from me, my brother, may God preserve you.
An ink that never fades and is also a dye; al-Rāzī mentioned it [as made] with anemone. 
(cont.)

\begin{tabular}{|c|c|c|c|c|}
\hline & $\mathbf{R}$ & $\mathbf{I B}=\mathbf{M} \mathbf{M}$ & мழ̣ & $\mathbf{Q}$ \\
\hline 2 & $\begin{array}{l}\text { Take some } \\
\text { anemones }\end{array}$ & Take the anemones & $\begin{array}{l}\text { Take the amount } \\
\text { you want of dark } \\
\text { red anemone as it } \\
\text { was mentioned and } \\
\text { named above, so } \\
\text { that you can under- } \\
\text { stand right away }\end{array}$ & $\begin{array}{l}\text { Take the amount } \\
\text { you like }\end{array}$ \\
\hline 3 & $\begin{array}{l}\text { and put them in a } \\
\text { thin Syrian bottle }\end{array}$ & $\begin{array}{l}\text { and put them in thin } \\
\text { bottles }\end{array}$ & $\begin{array}{l}\text { put it in a thin } \\
\text { Syrian or Maghribi } \\
\text { bottle, whichever } \\
\text { it is }\end{array}$ & $\begin{array}{l}\text { and put it in a thin } \\
\text { bottle }\end{array}$ \\
\hline 4 & $\begin{array}{l}\text { then bury it in the } \\
\text { humid dung }\end{array}$ & $\begin{array}{l}\text { you bury them in } \\
\text { the liquid dung }\end{array}$ & $\begin{array}{l}\text { then bury it in } \\
\text { the dung that has } \\
\text { different names } \\
\text { in my books } \\
\text { mentioned above, } \\
\text { but the meaning } \\
\text { is one; it is wisely } \\
\text { called sirqin or } \\
\text { sirfin, or "the bowels } \\
\text { of the horse," or } \\
\text { "the nature useful } \\
\text { to the nature," or } \\
\text { "the unstable fire"; } \\
\text { learn them all } \\
\text { from al-Marrākušī } \\
\text { [who wrote them] } \\
\text { here and there; the } \\
\text { manure has to be } \\
\text { humid }\end{array}$ & $\begin{array}{l}\text { then bury it in the } \\
\text { dung }\end{array}$ \\
\hline 5 & $\begin{array}{l}\text { substitute the dung } \\
\text { every three days }\end{array}$ & - & $\begin{array}{l}\text { and you have to sub- } \\
\text { stitute it with other } \\
\text { wet manure every } \\
\text { three days }\end{array}$ & $\begin{array}{l}\text { that you have to } \\
\text { substitute every } \\
\text { three days }\end{array}$ \\
\hline
\end{tabular}


(cont.)

\begin{tabular}{|c|c|c|c|c|}
\hline & $\mathbf{R}$ & $\mathbf{I B}=\mathbf{M} \mathbf{M}$ & Mழ̣ & Q \\
\hline 6 & $\begin{array}{l}\text { until you look at it } \\
\text { and [you will see } \\
\text { that] it has melted } \\
\text { and become liquid }\end{array}$ & $\begin{array}{l}\text { until they melt, } \\
\text { become like water } \\
\text { and liquefy. }\end{array}$ & $\begin{array}{l}\text { then check it until } \\
\text { you will see that } \\
\text { it has completely } \\
\text { melted and become } \\
\text { liquid }\end{array}$ & $\begin{array}{l}\text { until you look at it } \\
\text { and [you see that] it } \\
\text { has melted and has } \\
\text { become liquid }\end{array}$ \\
\hline 7 & $\begin{array}{l}\text { then you can write } \\
\text { with it wherever you } \\
\text { want }\end{array}$ & - & $\begin{array}{l}\text { then write with it } \\
\text { wherever you want } \\
\text { among the materials } \\
\text { we have mentioned }\end{array}$ & $\begin{array}{l}\text { then write with it } \\
\text { wherever you want }\end{array}$ \\
\hline 8 & and it will not fade & - & $\begin{array}{l}\text { not even a sentence } \\
\text { will fade }\end{array}$ & and it will never fade \\
\hline 9 & $\begin{array}{l}\text { not even if you put it } \\
\text { the water }\end{array}$ & - & $\begin{array}{l}\text { and, according to } \\
\text { what is reported, the } \\
\text { papyrus written with } \\
\text { it will not be cleared } \\
\text { out [if put] in the } \\
\text { water for days }\end{array}$ & $\begin{array}{l}\text { not even if you put it } \\
\text { in the water for days }\end{array}$ \\
\hline 10 & - & - & $\begin{array}{l}\text { al-Marrākušī } \\
\text { said - and he was } \\
\text { Muhammad b. } \\
\text { Maymūn b. 'Imrān } \\
\text { al-Marrākušī } \\
\text { al-Himyari - in the } \\
\text { year } 649 \text { while he } \\
\text { was in Baghdad, as } \\
\text { an addition to this } \\
\text { chapter: }\end{array}$ & - \\
\hline 11 & $\begin{array}{l}\text { if you want to make } \\
\text { it bright, put in it } \\
\text { gum arabic }\end{array}$ & - & $\begin{array}{l}\text { if you want to make } \\
\text { it bright, put the } \\
\text { proper amount } \\
\text { of powdered gum } \\
\text { arabic in it }\end{array}$ & $\begin{array}{l}\text { if you want to make } \\
\text { it bright put some } \\
\text { gum [arabic] in it }\end{array}$ \\
\hline 12 & - & - & $\begin{array}{l}\text { and it will be bril- } \\
\text { liant, beautiful and } \\
\text { shiny }[\ldots]\end{array}$ & $\begin{array}{l}\text { and it will be } \\
\text { marvellous }\end{array}$ \\
\hline 13 & - & $\begin{array}{l}\text { Then deal with the } \\
\text { papyrus and burn it }\end{array}$ & - & - \\
\hline
\end{tabular}


(cont.)

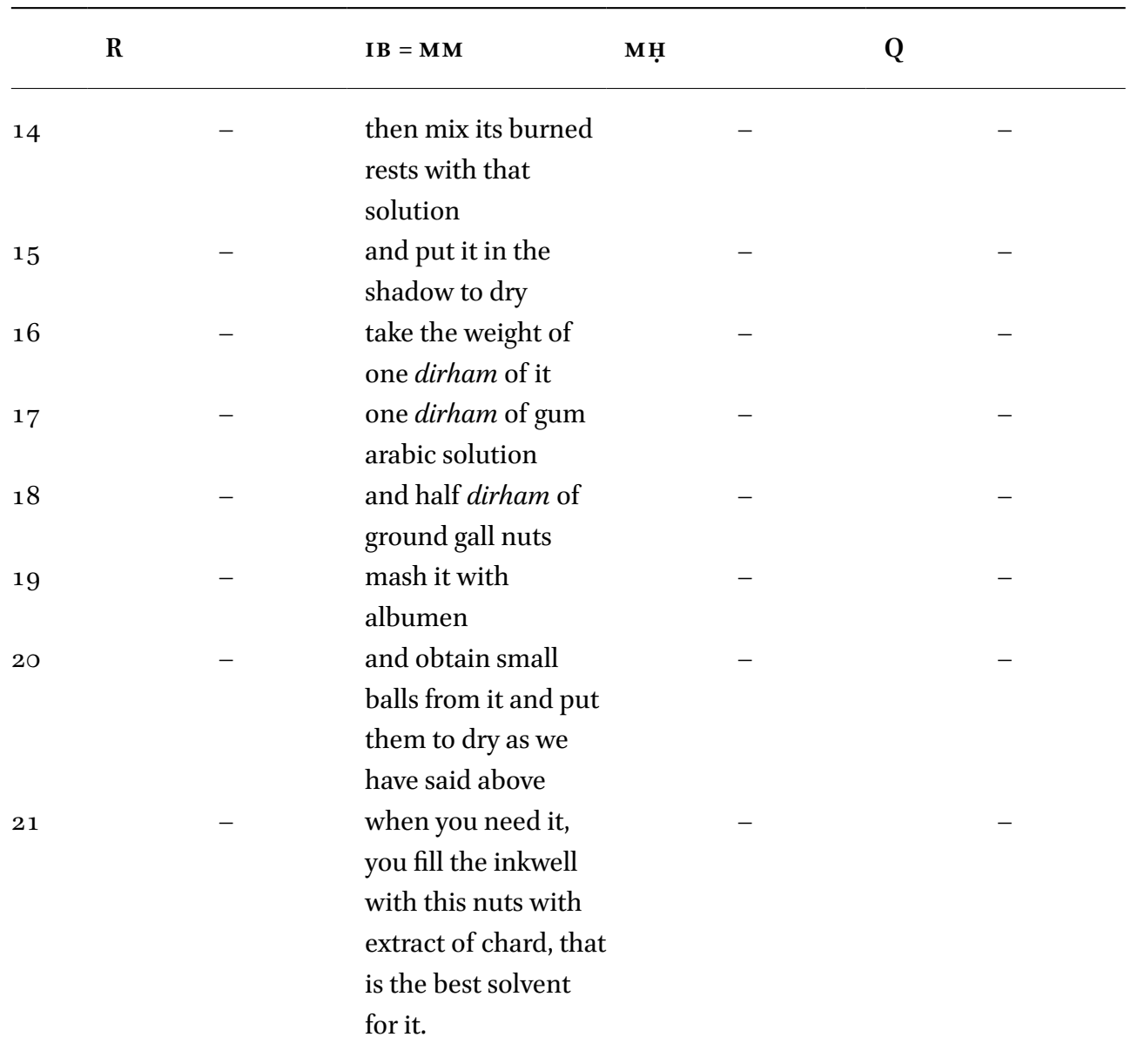

